\title{
DEVELOPMENT OF THE BAKERY PRODUCTS ASSORTMENT CORRESPOND WITH CONSUMER PREFERENCES
}

\author{
Формирование ассортимента хлебобулочных изделий, \\ соответствующего потребительским предпочтениям
}

\author{
Yalunina E.N. \\ Ялунина E.H.
}

\section{Abstract}

In the condition of the national economy transformation, there is a significant expansion of the consumer goods range. Its significant part unveils products of insufficient quality that does not meet last international requirements represent. The stage of the Russian economy development, and the market particularly is full abound in economic entities with differentiated organizational and legal form. Each of them has a certain type of economic activity: production, trade, or service. The priority aim of the market subject activities is to maximize profit through the human needs satisfaction. Taking into account the market oversaturation with consumer goods, the consumer generates new requirements for the product. Accordingly, the manufacturer forms a production plan, focusing on the requirements, and customers preferences. Since the financial and economic results of the market subject activity depends on the finished goods sale, and its life in the market directly, the problem of the logical assortment development is relevant today. There is a requirement for a new approach to ensure the development of enterprises in mature market relations. The assortment development technology has a variety of stages, one of which is marketing. The core of this stage is to provide the population with goods of high quality and alternative assortment. The World Health Organization (WHO), which provides quarterly analytical data, monitor the production of bread and bakery products. According to the WHO data, the average daily rate of bread consumption is $150-500 \mathrm{~g}$ per population unit. The Russian Federation belongs to the countries with a high level of bread and bakery products consumption. The social and cultural factors influence the bread consumption level. Bread and bakery products are socially significant goods. The government controls its sale prices, ensuring affordability to the population. The modern market of the bakery products is oversaturated and the producer reduces production. It occurs not because of the demand reduction, but because of the new enterprises (mini-bakeries) trying to hold the positions in this market segment.

\section{Реферат}

В условиях трансформации национальной экономики наблюдается существенное расширение ассортимента потребительских товаров, однако значительная часть его бывает представлена продукцией недостаточно высокого качества, не отвечающей последним мировым требованиям. Современный этап развития российской экономики, в частности развитие рынка, характеризуется изобилием хозяйствующих субъектов с дифференцированной организационно-правовой формой. Каждый из них имеет определенный вид экономической деятельности - производство, торговля либо услуга. Приоритетная цель деятельности рыночного субъекта - через удовлетворение потребностей человека получить максимальную прибыль. Учитывая

Keywords:

bread; bakery products; quality; management; competitiveness; evaluation; indicators; criteria; production technology; market

Ключевые слова: хлеб; хлебобулочные изделия; качество; управление; конкурентоспособность; оценка; 
показатели;

критерии;

технология

производства;

рынок

перенасыщение рынка потребительскими товарами, потребитель формирует новые требования к товару. Соответственно, производитель формирует план выпуска продукции, ориентируясь на требования и предпочтения покупателей. Поскольку финансово-хозяйственный результат деятельности рыночного субъекта напрямую зависит от реализации готовой продукции, от “жизни» этой продукции на рынке, то проблема логического формирования ассортимента сегодня актуальна как никогда - назрела необходимость нового подхода к обеспечению развития предприятий в условиях зрелых рыночных отношений. Технология формирования ассортимента товаров представлена многообразием этапов, один их которых - маркетинг. Задача данного этапа - обеспечить население страны товарами высокого качества и альтернативного ассортимента. Мониторинг выпуска хлеба и хлебобулочных изделий осуществляет Всемирная организация здравоохранения (ВОЗ), которая ежеквартально предоставляет аналитические отчеты. По данным ВОЗ, средняя ежедневная норма потребления хлеба составляет сегодня 150-500 г на единицу населения. Российская Федерация относится к странам с высоким уровнем потребления хлеба и хлебобулочных изделий. На уровень потребления хлеба прежде всего влияют социальный и культурный факторы. Хлеб и хлебобулочные изделия - это социально значимые продукты; цена их реализации контролируется государством, что обеспечивает их доступность для населения. Современный рынок хлебобулочных изделий перенасыщен, и производитель снижает выпуск данной продукции. Это происходит не из-за снижения спроса, а вследствие появления новых предприятий (например, мини-пекарен), пытающихся удержать свои позиции на данном сегменте рынка.

$W^{e}$ e define baking industry as the focused entrepreneurial activity and characterize it as dynamically developed. We believe that there is a unique feature of the bakery industry development: its products are essential goods ${ }^{1}$.

Modern bread and bakery products consumer imposes strict requirements for organoleptic, physical, and chemical parameters. When choosing products, the buyer aims at safety, packaging, shelf life ${ }^{2}$.

Each enterprise at the stage of the assortment policy development pay due attention to logistics and quality management of the made product ${ }^{3}$. Therefore, the enterprise development slows or

${ }^{1}$ Razvitie hlebopekarnoj promyshlennosti Rossijskoj Federacii na 2014 - 2016 gody: otraslevaya Celevaya programma, utverzhdena prikazom Ministerstva sel'skogo hozyajstva RF ot 19 marta 2014 g. № 83. URL: http://www.consultant.ru/cons/cgi/online. cgi?req $=$ doc\&base $=E X P \& n=458562 \# 006821340037941259$ Konsul'tant Plyus

${ }^{2}$ GOST 21094-75. Hleb i hlebobulochnye izdeliz. Metod opredeleniya vlazhnosti.

GOST 5670-51. Hleb i hlebobulochnye izdeliya. Metod opredeleniya kislotnosti.

GOST 5669-51. Hlebobulochnye izdeliya. Metod opredeleniya poristosti.

GOST 5667-65. Hleb i hlebobulochnye izdeliya. Pravila priemki, metody otbora obrazcov, metody opredeleniya organolepticheskih pokazatelej i massy.

GOST 8227-56. Hleb i hlebobulochnye izdeliya. Ukladyvanie, transportirovanie i hranenie.

${ }^{3}$ Chugunova O.V., Zavorohina N.V., Fozilova V.V. Razrabotka sovremennoj modeli kachestva prodovol'stvennyh tovarov na osnovanii integral'nogo analiza udovletvorennosti potrebitelej Izvestiya Ural'skogo gosudarstvennogo ehkonomicheskogo universiteta. 2012. № 1 (39). S. 181-187. stagnates. Baking industry companies do not give due consideration to the commodity assortment development, goods quality, and new customer demands.

The baking industry efficiency directly depends on the consumers requirements for products quality and range. Thus, the marketing research with economic justification should accompany new product launch in the manufacturer matrix, leading to an increase in the market share certainly. Additionally, this process should be due to the equipment replacement plan existing at the enterprise. In order to improve competitiveness, the market entity should concentrate on the assortment policy development, consumer requirements and product quality by improving the efficiency of the enterprise management integrated approach.

By product quality we mean a category that is an indicator for the consumer and affects the price. While price setting, a number of manufacturers target price reduction, as the government set limits on them. Therefore, they try to change the production technology due to the artificial raw materials, leading to the quality decrease and rise in production volumes. Practice shows that currently these producers experience difficulties because of the sharp decline in demand for their products. The mistake was that they ignored the new consumer reference points aimed at production safety. The production quality seems to provide long life of the enterprise and growth of production volumes. 
Let us consider the quality indicators classification, some analytical indicators and its calculation order, make conclusions from the data obtained, and give recommendations targeted the products quality increase.

The products quality boosting is a priority direction of the national economy dynamic development, the economic potential and enterprise management efficiency growth.

There is the traditional quality indicators classification':

a) function indicators that reflect extremely useful result from the product exploitation by the purpose and identify the application area of the finished goods;

b) product reliability indicators:

- universality;

- constancy;

- maintainability;

- with a certain usable life expectancy.

We suggest to clarify the classification and find the basis for characterizing the individuality of the assessed product in terms of reliability. Besides the enterprise can assess all factors, or choose some indicators below by the expert evaluation method.

Producibility indicators that characterize the choice of the technological preferred options stages aimed at achieving high productivity in the products manufacture using the utility function. Due to the technology a man achieve the following:

-balance between specialization and mass production;

- reasonable material costs ratio, efficient use of labor and financial resources.

Standardization and unification indicators that meet the market and public authorities' requirements and reflect the individuality of the manufactured goods. Individuality of manufactured goods, on the one hand, induces consumption, on the other hand, prevents mass production and product price reduction.

Ergonomic indicators evaluate the man interaction with the product through systematic work at the enterprises by creating working conditions in order to increase productivity.

Aesthetic indicators reflect the organizational and economic output modeling (form acceptability, composition completeness, marketable state, accessibility and sustainable information perception).

Transportability indicators show the products adaptability to the movement in space, taking into account the logistics approach.

Patent and law indicators determine the development and production rules of the goods of similar purpose. They are an element of achieving its competitiveness.

${ }^{1}$ COST 22851-77. Vybor nomenklatury pokazatelej kachestva promyshlennoj produkcii. Osnovnye polozheniya.
Environmental indicators determine the degree of adverse effect on the environment arising from the production, maintenance or consumption of products.

Safety indicators reflect product features during installation, maintenance, repair, storage, transportation and consumption.

Let us consider the indicator types of the bakery quality assess while developing assortment adapted to market relations in the national economy and sharply changing conditions of the food enterprises:

1) functional indicators reflect the maximum result from the products consumption and modern production ideology dogma laid in the products (bread caloric);

2) composition indicators determine the set of chemical elements in products or quality groups (for example, in bread - the weight fraction of sugar, salt, etc.);

3) reliability indicators stand for bread capability to keep in time within the established limits values all parameters characterizing the facility to perform the required functions in the specified modes and conditions of use, storage and transportation.

4) producibility indicators characterize labor productivity in the bread manufacture due to the technological operations.

5) social and economic indicators determine the products quality, i.e. the bread correspondence to hygienic, physiological, anthropometric and psychological properties of the person, taking into account the principle of value for money factor.

practically, the production quality improvement in the market subject activity is due to functionally-cost analysis application. The principle of this analysis is to reduce costs and improve quality simultaneously, that ensures the product competitiveness.

Let us consider the use of functional and cost analysis on the example of the PLC "Tagilkhleb"2.

The market entity PLC "Tagilkhleb" produces goods based on the requirements of normative and technical documentation and local regulations (technological instructions, recipes).

The production corresponds to the Russian Federation State Standards $16504-81^{3}$. On that basis by product quality we mean "quantitative and qualitative characteristics analysis of product properties according to the established technical requirements".

There is an organized production control in the activities of a market entity, that ensures the products quality. The control core is to limit deviations

\footnotetext{
2Otkrytoe akcionernoe obshchestvo "Nizhnetagil'skij hlebokombinat»: Godovoj otchet za 2016 god.

${ }^{3}$ GOST 16504-81. Sistema gosudarstvennyh ispytanij produkcii. Ispytaniya i kontrol' kachestva produkcii. Osnovnye terminy i opredeleniya.
} 
from organoleptic, and physical and chemical parameters. This contributes to the production organization of the economic entity in accordance with the Russian Federation standards requirements. A conformity certificate confirms products safety.

Now then take a closer look at these indicators.

We revealed organoleptic characteristics during bread and bakery examination and tasting. Then we estimated it on a thirty-point scale developed by the Moscow Technological Institute of the Food Industry. The maximum value of each indicator was 5 points. There was a description for each point used to conduct a comparative analysis. If the result was lower than 3 , we considered the product to be unsatisfactory and excluded it from the study.

Having studied the indicators characterizing the bakery products quality, we believe that they are focused on customer needs (taste, smell of fresh bread, usability) ${ }^{1}$.

Researchers determined physical and chemical indicators of bakery quality in the laboratory (humidity, sponginess, acidity, sugar and fat content, carbohydrates, swelling, wetness, etc.) and a time range for defining the physical and chemical parameters: an hour for products weighing 200 grams and three hours for the rest.

Allowable variation, \%: by the mass fraction of sugar is $\pm 1.0 \%$, for puff pastry - $\pm 2.0 \%$, by fat in dry matter $\pm 0.5 \%$.

The weight fraction limits of vitamins in products containing vitamin or vitamin and mineral complex is $1 \mathrm{mg}$ per $100 \mathrm{~g}$ at least $^{2}$.

The PLC "Tagilkhleb" maintains technical and chemical control products in the laboratory conditions stepwise:

1) raw material analysis (GOST, TU);

2) technological plans development for recipe and manufacturing plan formulating;

3) implementation of the innovative technological schemes of production.

${ }^{1}$ Grombah S.M. O kriteriyah ocenki sostoyaniya zdorov'ya detej i podrostkov. // Vestnik APN SSSR. 1981. № 1. S. 29-34.

${ }^{2}$ GOST 32124-2013: Izdeliya hlebobulochnye baranochnye. Obshchie tekhnicheskie usloviya.
The aim of technological and chemical control procedure is to determine the manufactured products quality.

The study revealed that the PLC "Tagilkhleb" pays due attention to the established requirements and to the quality assessment procedure based on the principle of "Responsibility to the Consumer". GOST $26987-86$ also concerns the sensorical aspects (appearance, proper shape, crusts color, surface condition, crumb characteristics and color) ${ }^{3}$.

The market entity PLC "Tagilkhleb" has specialized retailers that became the platform for demand and consumer preferences studying. The representative sample consisted of 1,200 people. The survey results indicated the $70 \%$ consumers requests satisfaction. The survey also revealed disadvantages in the assortment formation policy of the studied object. There was insufficient selection of wheat bread (36\%), bakery products from the "Healthy food" series (17\%), lach of danish for young people (18\%) on sale.

Customers assessed the quality assortment according to the three-point scale as satisfactory (48\%). $7 \%$ of consumers were not satisfied, but $45 \%$ were satisfied with the quality of bakery products.

According to the consumer demand studies, they are very fussy while choosing products. So, the enterprise "Tagilkhleb" takes a series of management decisions on the bakery availability, particularly the trade margins reduction from $5 \%$ to $20 \%$, the extension of the "social" bread types, campaigns in specialized stores such as "Nizkie Ceny" and "Vyberi Menya". In the retail chain, the bread and baguettes are served sliced. Due to this additional service, as noted by the customers, the enterprise has achieved a sales rise. Another management decision on the bread production was cutting it in half. This issue has also contributed to the increase in trade.

Thus, the modern bread market imposes requirements to the manufacturer, which force to carry out not only the mass bakery production, but also to

${ }^{3}$ GOST 26987-86. Hleb belyj iz pshenichnoj muki vysshego, pervogo i vtorogo sortov. Tekhnicheskie usloviya.

Expertise Results of the Physical and Chemical Characteristics

\begin{tabular}{|c|c|c|c|c|c|c|}
\hline \multirow{2}{*}{ Criteria } & GOST 26987-86 & \multicolumn{5}{|c|}{ Sample Characteristics } \\
\hline & $\begin{array}{l}\text { Target Features } \\
\text { for Wheat-Bread }\end{array}$ & Tagilskii & Solnechnyi & Semeinyi & Wheat-Bread & $\begin{array}{c}\text { Wheat-Bread } \\
\text { from First } \\
\text { Grade Flour }\end{array}$ \\
\hline Wetness, \% & Less than 43.0 & 40.0 & 39.0 & 41.0 & 40.0 & 38.0 \\
\hline Acidity, deg & Less than 3.0 & 2.6 & 2.4 & 2.3 & 2.4 & 2.8 \\
\hline Sponginess, \% & More than 72.0 & 74.0 & 75.0 & 73.0 & 72.0 & 73.0 \\
\hline
\end{tabular}


introduce a new type of product. Now it is necessary to develop the wide product range, to control its quality very strictly and to aim at consumer needs. Moreover, we have unveiled the low production level of bakery medical and dietary products and bread with the enhanced food and biological preventive qualities. Besides, bakery products have an important feature, they are easily interchangeable within the species and varieties. So, for example, the buyer can satisfy the need for bread by buying rye or rye-wheat bread, and the need for bakeries by purchasing puff or buns. This feature determines the specific and subject competition between bakery producers.

When developing a growth strategy, an enterprise should pay special attention to the assortment concept. Its essence lies in the commodity supply balance, consumer needs and the efficiency of using the combined potential of the economic entity. The main stages of the planned assortment concept should be expansion; deepening; limitation; ordering.
The essence of range expansion consists in the included additional types of goods or product groups.

The enterprise can diversified the range by offering consumer some kinds or types of products in various modifications that meet the unique customer desires.

The assortment limitation means that the manufacturer does not differentiate and expand its range due to the fact that the existing range meets the effective demand and the necessary financial indicators. Therefore, there is no need in the further expansion. Furthermore, the range expansion refusal takes place because of the limited production, financial and personnel capabilities of the enterprise.

The range ordering exists because a manufacturer reconsiders its range periodically, for example, sales unprofitable parts of the assortment with discounts. If the quality is higher than the competitors one, the product can be sold at higher prices or it will increase the market share.
Yalunina

\section{Ekaterina Nikolaevna}

Ялунина

Екатерина Николаевна

тел./Phone: (343) 221-27-17

E-mail:antitrust@usue.ru
Doctor of Economic Sciences, Professor, Professor of the Competition Law and Antitrust Regulation Department

Ural State University of Economics

620144, Russia, Ekaterinburg, 8 March St. / Narodnoy Voli St., 62/45

Доктор экономических наук, профессор, профессор кафедры конкурентного права и антимонопольного регулирования

Уральский государственный экономический университет 620144, РФ, Екатеринбург, 8 Марта / Народной Воли, 62/45 